\title{
Muslim-Pluralized
}

\section{History of Inter-Religious Dialogue in Bosnia and Herzegovina}

\section{From Force-Feeding to Sustainability?}

\author{
Ahmet Alibašić \\ Deputy Dean, Faculty of Islamic Studies, University of Sarajevo, Sarajevo, \\ Bosnia and Herzegovina \\ ahmet.alibasic@fin.unsa.ba
}

\begin{abstract}
Bosnia and Herzegovina has always been a multi-religious polity. While inter-religious relations were not always easy, the heterogeneity seems to be inherent to Bosnia. Significant resources were invested in the 1990s to alter that reality. The damage has been done but efforts have been made by various local and international actors to repair it. This article offers a brief account of the history of formal inter-religious dialogue in Bosnia, its main actors, and features. Major issues, types of dialogue, accomplishments and challenges lying ahead are also considered.
\end{abstract}

\section{Keywords}

interreligious dialogue - Bosnia and Herzegovina - religious communities - faithbased organizations 


\section{Historic Background: Religious Composition and Changing Balances}

Since its emergence in the twelfth century, Bosnia and Herzegovina $(\mathrm{BiH})$ has been a multi-religious and multi-ethnic polity. ${ }^{1}$ The three early religious groups - the Bosnian (Bн) Church, ${ }^{2}$ the Catholic Church, and the (Serb) Orthodox Church - later evolved into an even more colorful mosaic. On the eve of the Ottoman conquest in the mid-fifteenth century, the Bosnian church gradually disintegrated while Islam made significant gains under the Ottomans. In the sixteenth century, groups of Sephardic Jews who were expelled from Portugal and Spain settled in the country. The Austro-Hungarian occupation of 1878 brought scores of Protestants to the country. The following Socialist regime, between 1945 and 1990, enabled the formation of a new group of agnostics and atheists, which has apparently receded since the 1990 regime changes. ${ }^{3}$ Today these various religious identities tend to overlap with ethnic ones - Catholics commonly self-identify as Croats, Orthodox Christians as Serbs and Muslims as Bosniaks.

At different historical junctures, a different religious group tended to dominate the political arena, a phenomenon that regularly caused resentment amongst the other constituent communities. Around the twelfth century, the papacy enjoyed a dominant position and the Crusaders fought to cleanse the country of 'heretics'. During the Ottoman rule, 1463-1878, Muslims gained the upper hand and Islam became the official state religion. The Tanzimat reforms, between 1839-1856, reduced Muslim privileges and introduced a dual judicial system: One system of courts was founded on state legislation, while the other was based on religious precepts. Shari'a courts maintained legal authority only over personal matters of Muslim subjects. ${ }^{4}$ The subsequent Austro-Hungarian regime, 1878-1918, signaled the downfall of Islam as state religion. During the Habsburgs' reign, Catholics were informally privileged. The Kingdom of Yugoslavia that succeeded the Habsburgs, between 1918-1941, privileged the Orthodox Christian community. Owing to its short lifespan and decisive return of refugees after the war, the Independent State of Croatia, 1941-1945, had little effect on the balance between the communities although

1 Malcolm, Bosnia. This section is partially based on: Alibašić/Begović, Reframing the Relations between State and Religion, pp. 19-34.

2 Fine, The Bosnian Church.

3 Yugoslav censuses did not record religious affiliation, with the exception of the 1953 census when $12.6 \%$ of the population declared themselves to be atheists. See The Institute of Social Sciences, The Population of Yugoslavia, p. 40.

4 Karčić, Historija šerijatskog Prava [History of Shari'ah law], p. 216. 
war crimes of Ustasha and Chetnik movements have created bitter memories that have not healed to this date. The Socialist Yugoslavia, 1945-1990, however, initiated major changes. Similar to most other Communist regimes, the Yugoslav state upheld a separation between state and religion whereby religious structures were de facto subordinated to the new regime. ${ }^{5} \mathrm{~A}$ new atheist stratum filled key positions in the highest social and political ranks of the political system. Federal state attempts at disciplining ethno-religious divisions and engineering areligious Yugoslavs, however, failed to deliver.

The 1991 census showed that BiH had 1.9 million Muslims/Bosniaks, making $43.5 \%$ of the total population, 1.4 million or $31 \%$ Serbs and 760 ,ooo or $17 \%$ Croats. More than $90 \%$ of the total population of 4.38 million self-identified with one of the three major ethno-religious groups - Muslims/Bosniaks, Serbs and Croats. Only 6\% saw themselves as Yugoslavs. ${ }^{6}$ We note here that in 1991 only a handful of Bosnian municipalities (15/109) had an overwhelming majority of any one group (over 85\%; 2 Muslim municipalities, 6 Serb, and 7 Croat ones). On the contrary, 25/109 municipalities had no ethnic majority. Important for our purpose is the fact that despite continuous tensions, Bosnia and Herzegovina remained a pluralistic country throughout centuries - a phenomenon that warrants a separate study. During Yugoslav times it was often said that Bosnia is neither Catholic nor Muslim nor Orthodox, but Catholic and Muslim and Orthodox. Pluralism and heterogeneity seem to be natural for Bosnia - homogeneity is not. It takes massive war crimes to separate different communities. Life mixes them as can be seen in Central Bosnia even today. Several factors, or combinations thereof, could be at play here, including generally high levels of popular tolerance, inaccessible geography, resiliency of local religious identities or weak government penetration. In any case this demographic mixture certainly was not a result of Socialist social engineering. The country was equally if not even more mixed at the end of Ottoman and Austrian periods. Unfortunately, no period has been so detrimental to that diversity as the war of the 199os, which in many respects was a war against history as well, in the sense that heritage of unwanted communities was destroyed and their settlements renamed. Tragically, while the world is becoming more pluralistic, parts of Bosnia are less so.

In the late 1980s, these resistant collective identities were hijacked by the outgoing Communist and post-Communist national entrepreneurs in order to emphasize differences, consolidate authority, reconfigure borders and, when

5 Karčić, Šerijatski Sudovi u Jugoslaviji 1918-1941 [Shari'ah Courts in Yugoslavia 1918-1941].

6 Državni zavod za statistiku Republike Bosne i Hercegovine: Nacionalni Sastav Stanovništva. 
necessary, wage wars. ${ }^{7}$ The bloody Bosnian war, 1992-1995, was fueled by great nation-state projects of government in Belgrade and to a lesser extent Zagreb. ${ }^{8}$ The events of the war and violence, moreover, created and occasionally deepened existing ethno-religious divisions and left behind a modified demographic picture of the population. After the war, Bosniak politicians resisted holding a new census for years as they feared that it would legalize the results of genocide and ethnic cleansing and allow the public administration to be staffed in line with post-ethnic cleansing demographic reality. The census that eventually took place in 2013 showed a general decline of the population to 3.53 million, out of which $50.7 \%$ were Muslims, $30.75 \%$ were Orthodox and $15.19 \%$ Catholics. ${ }^{9}$

According to a 2018 International Republican Institute survey, conflict between ethnic and religious groups is considered by the Bosnian citizens to be the second and third biggest security threat facing their country $(16 \%$ and $10 \%$ of respondents respectively). Only organized crime is perceived as a bigger threat $(35 \%) .{ }^{10}$ The same survey found that $50 \%$ of Bosnian citizens selfdeclare as Muslims, $35 \%$ as Orthodox and $13 \%$ as Catholics. Overall, $13 \%$ of respondents say they are very religious, $49 \%$ consider themselves to be somewhat religious, $31 \%$ think of themselves as not very religious, while $5 \%$ think they are not religious at all. Two percent did not respond. ${ }^{11}$

Asked about the level of influence of religious communities in the country, $22 \%$ thought it was important but not overwhelming; $35 \%$ thought it was great; $27 \%$ said it was small while $10 \%$ opined that they had no influence whatsoever. The Bosnian population is evenly split on the impact of that influence. Only $11 \%$ consider such influence to be positive, while $39 \%$ think it is somewhat positive. Almost every fifth respondent (19\%) thinks it is negative while $26 \%$ think that it is somewhat negative. Muslims and Catholics have a more positive opinion of this influence than the Orthodox. ${ }^{12}$ Ethno-nationalist extremism is considered to be a much bigger threat than religious extremism ( $42 \%$ and $19 \%$ respectively).

\footnotetext{
7 Donia, Radovan Karadzic.

8 The role of Serbia in the Balkan wars of the 1990 is well known. For the role of Croatia, see: United Nations, International Criminal Tribunal for former Yugoslavia.

$9 \quad$ Federalni zavod za statistika BiH, Final Results of the 2013 Census.

10 International Republican Institute, Bosnia and Herzegovina, p. 14.

11 International Republican Institute, Bosnia and Herzegovina, p. 71.

12 International Republican Institute, Bosnia and Herzegovina, pp. 72-75.
} 


\section{Redefining Relations Between State and Religion}

The attack on the new born Bosnian state between 1992 and 1995 brought huge devastation to its social fabric. Ethno-religious identities and symbols became one of the main targets of violence. The Muslim community suffered the heaviest toll. Over $83 \%$ of all civilian casualties were Muslims. In total 832 mosques, 125 Orthodox and 65 Catholic churches were reportedly destroyed. ${ }^{13}$ The reconstruction process started in earnest immediately after the signing of the Dayton Peace Accords in December 1995 and lasted for about ten years before the International community prematurely decided to downgrade its engagement. It was during this period that the relationship between the state and religious communities was rearranged according to the international standards in this field. In the early 2ooos, international engagement was at its peak in Bosnia including its involvement in IRD via the establishment of the Interreligious Council (IRC, see below). As a result of the joint domestic and international effort and advice of the US freedom of religion expert Durham Cole, the Bosnian Parliament adopted the new Law on Freedom of Religion and Legal Status of Churches and Religious Communities in January of 2004. ${ }^{14}$ It was a paradigm shift from the previous Socialist model enshrined in the ${ }^{1976}$ Law on the Status of Religious Communities in which religion was proclaimed to be a private matter with very limited right to publicity. Religious communities were nominally separate but effectively controlled by the state.

The Law on Religious Freedom came as a crowning point of the newly instituted legal pyramid protecting human rights of Bosnian citizens: 1) the European Convention on Human Rights (ECHR) as an integral part of the Bosnian constitution, 2) the Constitution of $\mathrm{BiH}$ and 3) the constitutions of its two entities (Federation of BiH and Republic of Srpska). ${ }^{15}$ Subsequently a body of developing case law emerged. Finally, in 2019, two bilateral agreements were signed between the state and Catholic and Serb Orthodox Churches.

13 Hoare, Bosnia and Herzegovina, p. 19o. Omerdić, Prilozi izučavanju genocida [Contributions for the Study of Genocide]. Čabaravdić, Uništavanje božjih kuća "onih drugih" i njihova obnova.

14 Official Gazette of BiH 5/04.

$15 \mathrm{LiCODu}$, Constitution of BiH. Article 2.2 of BiH Constitution stipulates that the ECHR and its Protocols shall directly apply to $\mathrm{BiH}$ and its entities; and it shall have priority over all other law. Initially, the constitution of the Republic of Srpska positively discriminated the Serb Orthodox Church and the ethnic group: "The Serbian Orthodox Church (soc) shall be the church of the Serb people and other people of Orthodox religion" (Art. 28). The High Representative Wolfgang Petritsch subsequently annulled this provision preparing the ground of equality of all faiths in Bosnia. 
The Law on Freedom of Religion regulates core issues concerning the state-church relations, the legal status of religious communities, rules for establishing new religious communities and so forth. ${ }^{16}$ The Law recognizes the multi-confessional character of the country by granting all religious communities equal rights and obligations, without discrimination. In departure from the previous law, religion is granted the right to publicity and citizens are entitled to manifest it individually or collectively. The public proclamation of religion may only be restricted if necessary, in the interest of public safety, health, public morals, or the rights and fundamental freedoms of others (Art. 14.7).

The Law differentiates between three categories of religious organizations that are subject to different procedures of registration: 1) traditional ones (the Islamic Community, the Serb Orthodox Church, the Catholic Church and the Jewish Community);2) those registered before the enactment of the 2004 law; 3) and organizations applying for the first time. The first two categories only need to record their names, seat address, the person authorized to represent them, and the respective seal and stamp with the central registry of religious communities in the Ministry of Justice (Art. 16.3). Communities that fall under the third category are required to present additional documents in order to obtain official legal status including signatures of at least 300 citizenship-holding believers and a list of at least 30 founders (Art. 8 and 18).

The state may not grant the status of state religion to any religious community or interfere in the affairs and internal organization of religious communities. No community may obtain any special privileges from the state but the state may provide material assistance to religious communities without discrimination on any grounds thus allowing for state cooperation with faith groups. Such cooperation is confined mostly to the issues of common interest such as (religious) education, ${ }^{17}$ culture and charity although there are cases of support for church and mosque construction.

Two issues were not dealt with in this law: public budgetary support for health and social insurance of the clergy and restitution of religious property confiscated between 1945 and 199o. There is a wide societal agreement on these two issues but funding is an issue. While the provisions of this Law have generally been seen as liberal and meeting the international standards in this sector, one provision (Art. 5.f.) is considered problematic. According to this

16 For more details, see Karčić, Secular State and Religion(s), pp. 15-24. Alibašić/Begović, Reframing the Relations between State and Religion, pp. 22-25; Kovačević, The Legal Position of Churches and Religious Communities. 
provision, the formation of associations of religious officials or believers is prohibited without the consent of the relevant religious community authorities. Existing associations, established without the consent of the relevant church authority should seek such a consent.

The bilateral agreements between individual religious communities and relevant state authorities are expected to regulate in more detail the areas and terms of cooperation between them. The Catholic Church signed the framework agreement with the $\mathrm{BiH}$ state in 2007 while the Serb Orthodox Church did it in 2008. However, the Islamic Community has failed to get its agreement signed. The Council of Ministers adopted the draft agreement in the fall of 2015 but the Presidency has refused so far to sign it. Reportedly, the problem is the request to accommodate a few specificities of Islamic religious life such as Friday noon prayer, regular prayers, dress code, and food norms in public institutions. Despite the fact that the state expert team and the Council of Ministers have deemed the proposed agreement to be in line with the Law, former Croatian and Serb members of the Presidency Dragan Čović and Mladen Ivanić kept requesting modification to the agreement under various pretexts including the accusation that the Islamic Community wants to introduce Shari'ah ${ }^{18}$ and the request that the agreement be exactly the same as the other two. This last suggestion does not make much sense to the Muslim community as it has no interest in, for instance, safe communication with Vatican, priest privilege or holiday on Sundays. In the meantime, general elections took place in October 2018 and brought in new members of the Presidency. Currently only its Serb member, Milorad Dodik, is against the signing of the agreement. No resolution to the stalemate is in sight. In hindsight the Ic leaders believe that it was a mistake to let any agreement be signed before all are signed.

The separation of state and religious organizations seems to enjoy strong public support. Contrary to widely held suspicion of Muslims/Bosniaks wanting a religious state, most of them $(58 \%)$ "absolutely prefer a secular state" with another $21 \%$ "somewhat preferring a secular state". The comparable figures for Catholics/Croats are $56 \%$ and $22 \%$ and for Orthodox/Serbs are $49 \%$ and $30 \%$. More Serbs $(17 \%)$ prefer a religious state than either Bosniaks (14\%) or Croats $(13 \%) \cdot{ }^{19}$

\footnotetext{
18 Diab, Protiv 'diktature šerijata'.

19 International Republican Institute, Poll: Bosnians United in Opposing IS.
} 
As suggested by Mel Prideaux in this issue of JRAT, it is useful to distinguish informal inter-religious interaction from formal IRD in the sense of "contact between groups or individuals of different religious traditions where there is a formal and organised dimension."20

The informal interaction, other than conflicts, has been going on in Bosnia since its early days as it has always been a religiously diverse country. People traded goods and services, negotiated exchange of prisoners of war, assisted each other in their appeals for justice with various governments, ${ }^{21}$ rose together against governments (eg. Husein Gradaščević), resisted occupation (Austro-Hungarian), helped each other in times of terror (WWII), ${ }^{22}$ attended each others' (and joint) festivities and sacred places, supported (re)construction of places of worship, etc. During the war, religious humanitarian agencies provided aid across religious boundaries, especially Merhamet, Caritas and Benevolencia.

The history of this interaction and early dialogue has not been written down yet. A lot of this interaction and cooperation is overshadowed by "confessionalization" of all past conflicts, including pure political conflicts. For instance, it is often the case that in national historiographies of non-Muslim Balkan nations all uprisings against Ottomans are portrayed as Christian-Muslim fights. The fact that religious conflicts predated the Ottoman rule and the fact that the Balkan Muslims often rose against the Ottoman government which in turn used oppressive force (eg. Omer pasha Latas) has not altered this unilateral reading of history.

As for the history of formal IRD in Bosnia, perhaps its earliest chapter is the Yugoslav Commission for Relations with Religious Communities established by the Communists already in $1943 .{ }^{23}$ The commission evolved slowly over the next few decades. Its primary function was government control over religious communities, but limited inter-religious dialogue took place under its auspices. For instance, the opening ceremony of the Faculty of Islamic Studies in Sarajevo in 1977 was attended by a number of Catholic and Orthodox leaders. Another example could be the autonomy of the Macedonian Orthodox Church which was achieved with the assistance of the Commission. ${ }^{24}$ The

$20 \quad$ Prideaux, Legitimising Religion in Public, p. X.

21 Lašvanin, Ljetopis, p. 22o, p. 224; Benevolencija, Sarajevo Purim.

22 Brooks, The Book of Exodus.

23 Boeckh, Vjerski progoni u Jugoslaviji, pp. 403-431.

24 Hasanović, Fakultet islamskih nauka Univerziteta u Sarajevu, p. 22; Boeckh, Vjerski progoni uJugoslaviji, pp. 421 et seq., p. 429. 
disagreements over the role of various religious authorities during WWII was a major bone of contention in inter-religious relations after 1945. In some cases, as with Zagreb Archbishop Cardinal Alojzije Stepinac (1898-1960), those disagreements continue to cause misunderstanding until today between the Catholic and Serb Orthodox Church. ${ }^{25}$ On the eve of the 1990 wars, there was an attempt to establish more direct communication among religious communities. A newsletter "Zajedno" (Together) was launched but it was short lived and obviously not very successful.

The worrying aspect of the whole post-wwII Yugoslav experience, which deserves to be studied and understood especially by those who are skeptical about stronger presence of religion in the public square today, is the fact that Yugoslav society in those decades went through "drama of atheization"26 people attended the same (religious-less) schools, worked together in the same factories, served in the same army, and even inter-married. According to some statistics, in Banja Luka $18 \%$ of all marriages were inter-ethnic. None of that helped to prevent the conflict. One wonders if religion matters at all or if it is just a proxy for nationalism/ethnicity/tribalism in the Balkans (and elsewhere)?

During the war various international actors tried to engage religious communities but those efforts have not come to fruition. Overall, the opinions about the role of religion and religious communities in the 1990 wars differ and will be discussed below. The best documented segment of IRD history in $\mathrm{BiH}$ is the establishment and work of the Inter-Religious Council (IRC) since 1997. Its creation was initiated by William F. Vendley, former Secretary General of World Religions for Peace. ${ }^{27}$ The assessments of its performance vary. One could perhaps say that such differences are possible because the IRC glass is half-full: It has achieved a number of things but it could do much better. Among its successes are relatively good law on religious freedom, positioning of religious education in public schools, public condemnations of attacks on religious sites, an annual report on those attacks, a young theologians program, a new program supporting victims of sexual violence in conflicts, etc. ${ }^{28}$ Among its failures is IR Institute which was established in 2007 with a more robust mission in bridging the gap between religious communities and civil society. Perhaps two factors played a major role in the failure of the Institute. First, the

25 The Srpaska Times, Croat Daily Publishes Patriarch's Letter.

26 Ćimić, Drama Ateizacije.

27 Kostresevic, Interreligious Dialogue in Bosnia-Herzegovina, pp. 203-214.

28 For a detailed assessment of IRD in the Balkans see: Merdjanova/Brodeur, Religion as a Conversation Starter, pp. 97-124. 
fact that in that crucial stage the Serb Orthodox Church was represented by now retired bishop Vasilije Kačavenda (b. 1938) who obstructed the Institute's work. Second, the economic crisis that was setting in globally deprived the Institute of necessary economic means. On the other hand, the stable funding from state and other governments contributes to the longevity of the IRC. However, the IRC has also been criticized for nepotism and the way in which it spends public money donated by public authorities. ${ }^{29}$

Besides the IRC, which is a religious establishment organization, several other organizations and groups have been active in IRD. Some of the most significant ones have been: ABRAHAM, Pontanima, IMIC, and Nahla. ABRAHAM was an NGO established at the initiative of Eastern German Lutheran priest Christof Ziemer (b. 1941) which was active between 1997 and 2002. It was a youthful group which did a lot of good work in a short time span such as a series of workshops and publications entitled "The Place for the other in my religion and culture". Eventually it was overtaken by "professional managers" who abused the funds and lost donors, which effectively meant its closure.

Pontanima is an inter-religious choir established in 1996 as a project of the Franciscan Interreligious service "Eye to Eye". So far it has performed at over 400 events in BiH and around the world (Serbia, Croatia, Montenegro, Slovenia, Italy, Austria, Germany, France, USA, and China) and established itself as a leading peacebuilding project in the Balkans. It won numerous awards at home and internationally including Sarajevo City April 6 Award (2006), Pax Christi International Peace Award (2011), International Center for Interfaith Dialogue Qatar and Chirac Foundation (2016). Most recently, it has been recipient of the "Intercultural Achievement Award 2019" given by the Austrian Ministry of Europe, Integration and Foreign Affairs. ${ }^{30}$ The man behind the success of Pontanima is tireless Franciscan priest and peace-builder Ivo Marković. ${ }^{31}$

One of the most active women actors in IRD in Bosnia is Education and Research Center "Nahla" (ar. Honey Bee) in Sarajevo, established in May 2001. Its members are students, professional women, and housewives. The center is open to non-members too. Nahla's main fields of activity are education, social research, counselling, business support, youth and kids programs, sport and recreation, activism and cooperation. The organizational vision is an "educated and empowered woman who changes the world". Two of its core values

\footnotetext{
29 BiH News, U ime oca, sina i hiljade maraka?!

30 Oslobodenje, Nagrada "Intercultural Achievement Award" horu Pontanima.

31 See: Choir Pontamina on facebook.
} 
are openness and cooperation aimed at "building a culture of accepting the diversity". The organization is part of the new EU initiative "Global Exchange on Religion in Society". It is successfully run by a group of dedicated Muslim women who command wide respect both within the Muslim community and outside it, locally and internationally. Unlike other Muslim women's groups, it does not rely on an outside male ideological patron. The Center's local human resources, financial sustainability and ideological independence augur well for its future. ${ }^{32}$

The International Multi-religious Intercultural Center (IMIC) is yet another Franciscan IRD initiative in Bosnia. It provides a platform for promotion of IRD and development of discourse on justice and peace in the Balkans. The organization supports multi-religious, multiethnic and multicultural society, and promotes, inter alia, a culture of tolerance, peace and mutual understanding. IMIC supports peaceful encounter and understanding through bringing communities together in prayer, action, and day-to-day shared life. Its two flagship research projects are "Women, Religion and Politics" and "IRD through education and communication of the youth". IMIC was founded on 1oth of December, 1991, for the Anniversary of UN Declaration of Human Rights. For about two decades its key figure was Franciscan priest Dr. Marko Oršolić. ${ }^{33}$

Finally, Forum Bosnae is an NGO established in 1997, led by the Bosnian intellectual Rusmir Mahmutćehajić. It brings together individuals and institutions "committed to the creation of a future for Bosnia and Herzegovina as a harmonious and united society, based on dialogue, trust, and respect, and on best practice in the fields of human rights protection, the rule of law, and democracy." So far the Forum has produced dozens of inter-religious events and publications. $^{34}$

The key features of the post-Socialist Bosnian context of relevance to the IRD are: 1) overlapping ethnic and religious identities, 2) presence of three main highly hierarchical religious communities, 3 ) weak government (except in the Republic of Srpska) and 4) influential international community. In the marriage of ethnic and religious identities religion is a weaker side often abused

\footnotetext{
32 See NAHLA Center for Education and Research.

33 See IMIC Internacionalni Multireligijiski Interkulturalni Centar.

34 See IMIC.
} 
and instrumentalized for nationalistic purposes. The destruction of religious sites during the very secular wars during the 199os is a good example of this manipulation. That has motivated some to controversially conclude that those wars were religious in nature. Presence of religious symbols and discourse in war mobilization efforts, destruction of religious sites or presence of clergy among soldiers is the key argument supporting this claim. The emblematic of this role is the scene of Orthodox priest blessing a special Serbian Police unit "Red Berets" or "Scorpions" in summer 1995 who afterwards went on to kill a few Srebrenica boys and men while recording the execution. ${ }^{35}$ Others offered public religious services for sentenced war criminals or defended such practices. ${ }^{36}$ On the other hand, several counter-arguments are put forward. First, those who ignited them were not particularly religious, if at all (Milosevic). Second, whenever political and religious leaders held different positions it was the will of politicians that prevailed. Third, between April 1992 and March 1994 Bosnia witnessed two realignments. In March 1992 Muslims and Catholics overwhelmingly voted in the Independence referendum for their country to leave Yugoslavia while most Serbs abstained. In the first year of war Croatian and Muslim/Bosniak forces fought together. However, in early 1993, after Serbian and Croatian leaders agreed on the division of Bosnia, the Croatian Defense Council allied itself with the Army of Rs just in order to come back to the side of the Bosnian Army in April 1994 after the US-brokered Washington agreement. One could go on arguing the claim that the 1990 wars were not religious wars but it is obvious that identities do not change as fast as alliances did during the war. Interests do. ${ }^{37}$ The ultimate result of this mixing of religion and ethnicity is that religious communities and authorities are not autonomous in their dealings with other communities. Therefore the IRD cannot be analyzed independently from the toxic political context contaminated with nationalistic hatred.

The presence of three very strong religious organizations which have secured legal semi-oligopoly on their three religious traditions narrows the space for other actors in all things religious including IRD. Besides, those communities command the bulk of religious recourses, be it authority, intellectual power, spaces, money or permissions. It often happens that permissions to participate

35 Bosnapatriot on Youtube, ŠKORPIONI-U Zločinačkom Pohodu (1/3).

36 Bećirbašić, Srbi se neće vratiti.

37 For more on this topic see: Sells, The Bridge Betrayed Religion and Genocide in Bosnia; Tomanić, Srpska crkva u ratu i ratovi u njoj; Vrcan, Lacerated Between Enormous Challenges and Inadequate Responses, pp. 43-6o; Vukomanović, The Religious Dimension of the Yugoslav Conflicts. 
in dialogue events are denied to the clergy or withdrawn at the last minute. In some communities those that show more proclivity to dialogue than the rest of the community are transferred outside the country or marginalized within their own community.

Finally, a weak state means that, unlike in some other countries, local religious communities are under no pressure from public authorities to sit and dialogue. On the contrary, those authorities, if nationalistic, might be the ones who discourage openness and cooperation across religious lines. However, one could say that a surrogate for the state exists in the form of the infamous "International Community". The 199os Balkan wars were internationalized to a significant extent. Due to that fact, most groups tried to develop good relations with the outside world and project an image of a cooperative party as non-cooperation was often costly. Thus all major IRD initiatives came from abroad including the IR Council and IR Institute. The list also includes various IR events: two papal visits in 1997 and 2015, the European Council of Religious Leaders (ECRL) meeting in Sarajevo in 2003, two Building Bridges seminars in 2005 and 2018, the St. Egidio event in 2012, various seminars and conferences by Konrad Adenauer Stiftung, etc. The strong role of international actors in the conceptualization, funding and sometimes running of IR projects raises the question of sustainability of these activities. In that sense, the IRD is no different from the Bosnian civil society in general. As of the moment it is difficult to say how much of the IRD is organic and self-sustainable, as the proper mapping exercise that could assist in ascertaining that sustainability has not yet been conducted.

However, all is not doom and gloom. This international-domestic partnership has produced some unique results. One of them is the master's program "Inter religious Studies and Peace Building" jointly run by three theological faculties in Bosnia. The idea came from the Catholic Relief Services Office in Sarajevo in 2016 to launch a joint master's program by the Faculty of Islamic Studies, Catholic Theological Faculty and Orthodox Theological Faculty. The first two are part of the University of Sarajevo while the third is a member of the East Sarajevo University. The program has enjoyed mostly moral support from a number of other organizations including the three religious communities. The US Embassy and USAID have provided significant support to it too. The program has so far run smoothly. In October 2019 the program admitted 12 new students. It was encouraging to listen to highly motivated candidates explain their reasons for choosing this program which does not promise much in terms of a career path. Whether this is a sign of better IRD times remains to be seen. 
The IRD in BiH has so far mainly dealt with the following issues:1) Religion-State relations, 2) relations with religious Other, including non-religious, 3) family values and public morality, and 4) truth and reconciliation. As colleagues writing about IRD in East Germany observed, "IRD is - at least under the conditions of a low degree of religious affiliation - also a phenomenon of positioning religion within public space." ${ }^{38}$ Having suffered under the previous Socialist regime, all major religious organizations have considered the ideological nature of the state ${ }^{39}$ and its relations with those organizations to be a major issue to be settled. In the 199os some illiberal and discriminatory solutions were adopted especially in the RS where the Serb Orthodox Church was constitutionally privileged for years. The Office of the High Representative scrapped that article and eventually all three communities agreed on a model of statechurch relations acceptable to all enshrined in the above-mentioned Law on Freedom of Religion. While some issues are considered as still open for discussion, such as restitution and public financial support for religious communities, the most important ones have been settled at least conceptually to the satisfaction of major religious hierarchies. In practice, however, being a minority in a certain area often increases chances of discrimination or threat. One of the remaining steps in this regard is the signing of a framework agreement between the state and the Islamic Community discussed above.

The relations with the religious Other, including non-religious, has received a lot of attention in the post-war Bosnian society. This covers topics such as the place for the other in various religious traditions and trust building. Generally, the Catholic Church and the Islamic Community have been very active in this field. The representatives of the soc have been initially somewhat reserved. A major change occurred after the burning of Orthodox churches in Kosovo

38 Körs/Lehmann, Interreligious Dialogue (IRD) Activities in East Germany, p. XX.

39 The inter-ethnic dispute on the nature of the Bosnian state has not featured prominently in the IRD while it constitutes a major topic in the country's politics. The question is whether Bosnia should be organized as a country of citizens or a polity of three ethnic communities. Bosniaks, being a half of the population, are generally in favor of the civic principle, while Serbs and Croats push for an association of ethnic communities. Finding the right balance between these two legitimate positions is a challenge in itself. What aggravates the situation is lack of consistency. Somehow, whenever a community is in a majority at a level of governance (being it city, canton, entity, or state) it favors the civic principle while as a minority it opts for parity. Both principles are embedded in the country's constitution. International organizations such as the Venice Commission and ECHR have generally ruled in favor of the rights of citizens. However, this issue requires a separate discussion which goes beyond the scope of this paper. 
in March 2004. In principle, the Catholic Church, represented by Sarajevo and Banja Luka bishops, has followed the Vatican Two teachings. However, its Mostar bishop has mostly avoided any inter-religious encounters. ${ }^{40}$ (It is in the absence of any IR events and even symbolic gestures that one starts to appreciate their importance). On the other side, some Bosnian (but not Herzegovinan) Franciscans have been very critical of their church for not doing enough. The summary of the Islamic Community is given in the semi-official document The Platform of the Islamic Community in Bosnia and Herzegovina for Dialogue from 2006. The first section of the document contains basic principles that should guide IRD on issues of religious diversity and coexistence. The second section deals with inter-ethnic and international relations, human rights and violence. The third section highlights the Bosnian Muslim perspective of the 1991-1995 war in $\mathrm{BiH}$, and the post-war restoration of our pluralistic society. ${ }^{41}$ The platform is a relatively rare and clear statement of the Islamic Community position on issues of dialogue and cooperation. It has received some positive appraisal among Catholic theologians in the country. ${ }^{42}$

The most divisive topic in IRD in Bosnia has been truth and reconciliation. While all three major communities have parallel truths, the soc has been most reluctant in admitting this topic to the discussion table, which was explicitly stated in the negotiations preceding the establishment of the IR Institute. This attitude is particularly worrying having in mind the statistics which relate around $85 \%$ of all war crimes to the Serb forces in Bosnia. ${ }^{43}$ With the exception of the former bishop of Trebinje now in Dortmund, Bishop Grigorije (b. 1967), no other soc official has visited the civilian victims site. Soc is yet to condemn war crimes in non-relativizing terms. Unfortunately, things have not improved much with the passage of time. As recently as in January 2016 Serb Patriarch Irinej stated that "the RS was established on Divine truth and justice" to which the Catholic Bishops Conference reacted with an open letter calling him to be a leader in acknowledging the truth and advocating the rights of all victims. ${ }^{44}$ For months after this letter relations between the two churches were sour. However, a positive step was recently made in the area of support to the victims of sexual violence during the war. The Faculty of Islamic Studies in Sarajevo has invited Fra Ivo Markovic to speak about his family story which is not pleasant at all for the Muslim audience to hear. His father and uncle were

40 Bishop Perić back in 1994 wrote that ecumenical work (let alone IRD) is Sisyphus work. See Perić, Tomo Vukšić, pp. 334-337.

41 Islamska Zadjenika: Nacrt platforme Islamske zajednice u BiH za dijalog.

42 Zovkić, Dialogue between Catholics and Muslims, pp. 118-120, pp. 343 et seq.

43 Cohen, C.I.A. Report on Bosnia, p. A1.

44 Katoliča Tiskovna Agencija, Reakcija Biskupske konferencije BiH. 
killed by Muslim members of the Bosnian Army. Other non-Muslims were invited to speak about their war experience. The IC has acknowledged that war crimes were committed "in the name of Islam or Muslims (such as the cases of Kazani, Grabovica and others, as well as the case of partial construction of a mosque in Bradina on a piece of land privately owned by a Serb)." 45 However, the IC is convinced that those were and are incidents that have never turned into a policy or a phenomenon. The IC is particularly proud not to have been involved in acts of inciting and covering crimes such as removal of remains of mined and burned religious facilities, relocation of mass graves, construction of its own religious structures on locations of those belonging to others, etc."46 Recently the IC has committed to visits of any place of war crimes against civilians. ${ }^{47}$ The next big challenge for the soc in this regard is the implementation of the ECHR decision in the case of Orlović and Others v. Bosnia and Herzegovina from 1 Oct. 2019, which ruled that the Bosnian state has three months to remove an orthodox church built on the private property of Fata Orlović. $^{48}$

Among the issues that so far have not received almost any attention in the IRD are the issues of depopulation or emigration of Bosnian citizens of all affiliations to Western Europe and the arrival of immigrants mainly from the East. Family values and public morality are another subject around which there has not been much talk so far but that might change now that the first Pride parade happened in Sarajevo in 2019.

The inter-religious dialogue in post-199o Bosnia has been going on in several strands: 1) clerical, 2) academic, 3) civic faith-based organizations (FBO, including women in dialogue), and 4) other NGOs. Due to the dominant presence of three tightly knit religious communities, the prevalent type of IRD is the clerical one, taking place through the IRC and outside it among the three communities at national and local levels. (Ecumenical dialogue between the Serb Orthodox Church and Catholic Church gained some steam during the

\footnotetext{
45 The Bradina mosque was demolished in 2008. See BIR Radio, How the mosque on Badina was demolished.

46 Islamska Zadjenika: Nacrt platforme Islamske zajednice u BiH za dijalog.

47 Mentioned in: The statement of the deputy Grand Mufti Husejin Smajic at an IRC meeting; an interview with Emir Kovacevic in Sarajevo on October 14, 2019.

48 HUdoc European Court of Human Rights, Case of Orlović and Others V. Bosnia and Herzegovina.
} 
Benedict XVI papacy). The second type is the academic dialogue involving academics of various traditions. This type is ongoing among religious communities (eg. Building Bridges) ${ }^{49}$ but also outside it (Forum Bosnae). The third type is faith-based civic IRD practiced by the likes of the now defunct Abraham society, International Multi-religious Intercultural Center (IMIC) or Muslim women ғво "Nahla". Foundations like Konrad Adenauer Stiftung often support these associations. In addition to usual challenges facing IRD, this type of dialogue faces an extra challenge of having to deal with traditional religious communities who are quite protective of their religious traditions, which they would rather monopolize. Finally, ordinary NGOS occasionally engage in IRD activities (eg. Foreign Policy Initiative)..$^{50}$ They do so out of general civic motivation or simply because there is funding for it.

Despite undeniable achievements, the IRD in Bosnia and Herzegovina faces numerous challenges including the following: First, the already mentioned marriage between religious and ethnic identities is bound to keep making the IRD task difficult in the context of heightened ethnic relations. Second, dealing with the past intellectually and psychologically will remain the elephant in the IRD room. Many see themselves as (the biggest) victims of the past both distant and recent. Simultaneously, denial of others' suffering is rampant. Multi-perspectivity is mostly absent from exclusivist narratives. The worrisome fact is that even the findings and decisions of UN courts are not accepted. The real work on this issue is yet to be done. Third, the IRD is about people committed to dialogue. The achieved levels of inter-religious understanding and cooperation can be attributed to concrete people like the former Grand mufti Mustafa Ceric, Cardinal Vinko Puljic, Grand Mufti Kavazović, Bishop Grigorije, Prof. Mato Zovkić, Prof. Mile Babić, Fra Ivo Marković, Fra Ivan Šarčević, Fra Marko Oršolić, Ms Sehija Dedović, and similar enthusiasts. The constant challenge is to recruit new actors who are willing and have stamina to swim against the tide. The future of IRD rests on the ability of those people to engage younger colleagues either as direct participants or supporters. Finally, in terms of resources, a lot more effort has been invested in the destruction of the $\mathrm{BiH}$ plural society than in its reconstruction. That has to change if we want to see major results. Otherwise, IRD will remain an aberration in our societies filled with hatred and chauvinism where proponents of dialogue are often exposed to different forms of pressure including bullying.

In a recent interview, a veteran of IRD, Marko Oršolić, a retired Franciscan priest, opined that IRD in Bosnia is mostly honest but insufficient. Stereotypes

49 Berkeley Center for Religion, The Building Bridges Seminar.

50 Foreign Policy Initiative BH, About us. 
and traditionally held beliefs are still stronger than theological teachings; local priests do not listen to their leaders who are generally dedicated to IRD but too often lack courage to lead instead of trying to detect the feelings of their communities. ${ }^{51}$ One tends to agree with Oršolić that IRD in Bosnia today is more about courage and leadership than theology. Religious authorities are inclined to follow politicians and their own flock especially when dealing with the past. Majority-minority dynamics are also at work. Minorities are more interested in dialogue while majorities seem to think that they do not need it. That attitude could prevail in the world showing less and less respect for values and principles and more for identitarian politics.

\section{Biography}

Ahmet Alibašić is Deputy Dean for Academic Affairs at the Faculty of Islamic Studies, University of Sarajevo. He is a teacher of Islamic civilization courses and author of a book on Islamic opposition in the Arab world, several articles and edited books dealing with Islam in Europe, human rights in Islam and the Muslim world, inter-religious dialogue, and church-state relations. Most recently he is one of the editors of Yearbook of Muslims in Europe (Brill, 20092020) and Journal of Muslims in Europe.

\section{Bibliography}

Alibašić, Ahmet/Begović, Nedim: Reframing the Relations between State and Religion in Post - War Bosnia: Learning to be Free, in: Journal of Balkan and Near Eastern Studies 19 (1/2017), pp. 19-34.

Alibašić, Ahmet: A Problem that Does Not Have to Be: Religious Education in Public Schools, in Bosnia and Herzegovina, in: Ahmet Alibašić et al. (ed.s): Religija $i$ školovanje u otvorenom društvu: Preispitivanje modela religijskog obrazovanja u Bosni i Hercegovini. Sarajevo: Fond otvoreno društvo Bosna i Hercegovina 20o9, pp. 107-110.

Benevolencija: Sarajevo Purim, https://jews.ba/post/34/Sarajevski-Purim (date of last access: 01.02.2020).

Bećirbašić, Belma: "Srbi se neće vratiti," interview with Vanja Jovanović, BH Dani, Br. $5^{84}, 22.08 .2008$.

$5^{1}$ See $I M I C$. 
Berkeley Center for Religion, Peace and World Affairs, The Building Bridges Seminar, https://berkleycenter.georgetown.edu/projects/the-building-bridges-seminar (date of last access: 02.02 .2020 ).

BiH News: $U$ ime oca, sina i hiljade maraka?! 29.10.2018, https://www.rtvbn.com/ 3927389/u-ime-oca-sina-i-hiljade-maraka (date of last access: 18.05.2020).

BIR Radio: Kako je srušena džamija na Bradini [How the mosk was demolished], https://www.bir.ba/index.php/vijesti/bih/item/9209-kako-je-srusena-dzamija-nabradini (date of last access: 15.02.2020).

Boeckh, Katrin: Vjerski progoni u Jugoslaviji 1944-1953: staljinizam u titoizmu, in: Časopis za suvremenu povijest 38 (2/2006), pp. 403-431.

Bosnapatriot on Youtube, ŠKORPIONI-U Zločinačkom Pohodu (1/3), https://www.youtube.com/watch?v=84_LdFAA3co (date of last access: 18.05.2020).

Brooks, Geraldine: The Book of Exodus: A double rescue in wartime Sarajevo, https:// www.newyorker.com/magazine/2007/12/o3/the-book-of-exodus (date of last access: 15.02 .2020$)$.

Čabaravdić, Sabina: Uništavanje božjih kuća „onih drugih“ i njihova obnova [Destruction of God's houses "of others" and their restoration], https://www.slobodnaevropa. org/a/tema_sedmice_vjerski_objekti/1733524.html (date of last access: 15.02.2020).

Choir Pontanima: Facebook Page of Choir Pontanima, https://www.facebook.com/ pontanima/ (date of last access: 18.05.2020).

Ćimić, Esad: Drama ateizacije. Sarajevo: Zavod za izdavanje udžbenika, 1971.

Cohen, Roger: C.I.A. Report on Bosnia Blames Serbs for 90\% of the War Crimes, in: The New York Times, o9.03.1995, p. A1, https://www.nytimes.com/1995/o3/o9/world/ciareport-on-bosnia-blames-serbs-for-9o-of-the-war-crimes.html (date of last access: 26.04.2020).

Diab, H.H.: Protiv 'diktature šerijata', https://www.vecernji.hr/vijesti/protiv-diktatureserijata-1240422 (date of last access: 08.02.2020).

Donia, Robert J.: Radovan Karadzic: Architect of the Bosnian Genocide. City of Cambridge: Cambridge University Press, 2014.

Državni zavod za statistiku Republike Bosne i Hercegovine: Nacionalni sastav stanovništva: Rezultati za republiku po opštinama i naseljenim mjestima [National Composition of Population: Results by Municipalities and Settlements]. Sarajevo: Državni zavod za statistiku Republike Bosne I Hercegovine, 1993, https://fzs.ba/ (date of last access: 25.05.2020).

Federalni zavod za statistika BiH: Final results of the 2013 Census, http://fzs.ba/index. php/popis stanovnistva/popis-stanovnistva-2013/konacni-rezultati-popisa-2013/ (date of last access: 16.10.2019).

Fine, John V.A.: The Bosnian Church: A New Interpretation - A Study of the Bosnian Church and its Place in State and Society from the 13th to the 15th Centuries. London: Saqi/Bosnian Institute, 2007. 
Foreign Policy Initiative BH: About us, https://vpi.ba/en/about-us/ (date of last access: 18.05.2020).

Hasanović, Zuhdija (ed.): Fakultet islamskih nauka Univerziteta u Sarajevu 1977-2017. Sarajevo: FIN i El-Kalem, 2017.

Hoare, Marko Attila: Bosnia and Herzegovina: Genocide, Justice and Denial. Sarajevo: CNS, 2017.

HUdoc European Court of Human Rights: Case of Orlović and Others V. Bosnia And Herzegovina, https://hudoc.echr.coe.int/eng\#\{“itemid”:[“oo1-196155”]\}, (date of last access: $15 \cdot 02.2020)$.

IMIC International Multi-religious Intercultural Center, 29.06.2018, https://imic.ba/ portal/?p=451 (date of last accessed: 18.05.2020).

International Republican Institute: Poll: Bosnians United in Opposing IS; Divided on U.S., EU and Russia, 2017, https://www.iri.org/resource/poll-bosnians-unitedopposing-divided-us-eu-and-russia (date of last access: 18.05.2020).

International Republican Institute: Bosnia and Herzegovina: Understanding Perceptions of Violent Extremism and Foreign Influence: March 29, 2018-April 12, 2018, https://www.iri.org/sites/default/files/march_28-april_12_2018_bih_poll.pdf (date of last access: 01.02.2020).

Islamska Zadjenika: Nacrt platforme Islamske zajednice u BiH za dijalog [Draft Platform of the Islamic Community in Bosnia and Herzegovina for Dialogue], 21.01.2009, https://static.islamskazajednica.ba/fetve-i-rezolucije/5756-nacrt-platformeislamske-zajednice-u-bih-za-dijalog (date of last access: 08.02.2020).

Karčić, Fikret: Šerijatski Sudovi u Jugoslaviji 1918-1941 [Shari'ah Courts in Yugoslavia 1918-1941]. Sarajevo: Visoko islamsko starješinstvo, 1986.

Karčić, Fikret: Historija šerijatskog prava [History of Shari'ah law]. Sarajevo: Faculty of Islamic Studies, 2005.

Karčić, Fikret: Secular State and Religion(s): Remarks on the Bosnian Experience in Regulating Religion and State Relations in View of the New Law on Freedom of Religion, in: Stefan Schreiner (ed.): Religion and Secular State. Zurich/Sarajevo: European Abrahamic Forum and Interreligious Institute 2008, pp. 15-24.

Katoliča Tiskovna Agencija: Reakcija Biskupske konferencije BiH na izjave patrijarha Irineja [Reaction of the Bishops' Conference of $\mathrm{BiH}$ to the statements of Patriarch Irinej], 15.02.2016, http://www.ktabkbih.net/info.asp?id=63411 (date of last access: 15.02.2020).

Kostresevic, Milan: Interreligious Dialogue in Bosnia-Herzegovina, in: Studies in Interreligious Dialogue 26 (2/2016), pp. 203-214.

Kovačević, Emir: The Legal Position of Churches and Religious Communities in Bosnia and Herzegovina, in: Silvo Devetak et al. (eds.): Religion and Democracy in Moldova. Maribor Chisinau: ISCOMET/ASER, 2005. 
Körs, Anna/Lehmann, Karsten: Interreligious Dialogue (IRD) Activities in East Germany. Low Levels of Activities within Official Organizational Structures, in: JRAT 6 (2/202O), pp.

Lašvanin, Nikola: Ljetopis. Sarajevo/Zagreb: Synopsis, 2003.

LiCODu: Constitution of BiH 1995, http://licodu.cois.it/?p=919\&lang=en (date of last access: 08.02.2020).

Malcolm, Noel: Bosnia: A Short History. London: Macmillan, 1994.

Merdjanova, Ina/Brodeur, Patrice: Religion as a conversation starter: interreligious dialogue for peacebuilding in the Balkans. London: Continuum International Publishing Group, 2009.

NAH LA Center for Education and Research: Website, https://nahla.ba/ (date of last access: 18.05 .2020$)$.

Omerdić, Muharem: Prilozi izučavanju genocida nad Bošnjacima, 1992-1995 [Contributions for the Study of Genocide against Bosniaks 1992-1995]. Sarajevo: El - Kalem, 1999 .

Oslobodenje: Nagrada "Intercultural Achievement Award" horu Pontanima, o9.10.2020, https://www.oslobodjenje.ba/o2/kultura/muzika/nagrada-interculturalachievement-award-horu-pontanima-497123?fbclid=IwARıfMGKiT6FPZi_qew_Ke _7egKruRBIh8PCWGZEIdWOsbxidWoyug261Ns (date of last access: 15.02.2020).

Perić, Ratko. Tomo VUKŠIĆ, Međusobni odnosi katolika i pravoslavaca u Bosni i Hercegovini (1878-19o3). Povijesno-teološki prikaz, in: Diacovensia 2 (1/1994).

Prideaux, Mel: Legitimising Religion in Public: Inter Religious Dialogue and the Established Church in England, in:JRAT 6 (2/2020), pp. X-X.

Radić, Radmila: The State, Serbian Orthodox Church and Roman Catholic Church from 1946 until The Mid-Sixties, in: Milan Vukomanović/Marinko Vučinic (eds.): Religious Dialogue in the Balkans: The Drama of Understanding. Belgarde: Belgrade Open School, 2005.

Sells, Michael A.: The Bridge Betrayed Religion and Genocide in Bosnia. California, CA: University of California Press, 1998.

The Institute of Social Sciences: The Population of Yugoslavia. Belgrade: Publisher, 1974.

The Srpska Times: Croat daily publishes patriarch's letter to pope on Stepinac. 05.01.2016, http://thesrpskatimes.com/croat-daily-publishes-patriarchs-letter-to-pope-onstepinac/ (date of last access: 01.02.2020).

Tomanić, Milorad: Srpska crkva u ratu i ratovi u njoj. Beograd: Medijska knjižara Krug, 2001.

United Nations: International Criminal Tribunal for former Yugoslavia, https://www. icty.org/en/case/prlic (date of last access: 08.02 .2020 ).

United Nations: Prlić et al. (IT-04-74), https://www.icty.org/en/case/prlic (date of last access: 08.02 .2020 ). 
Vrcan, Srđan: Lacerated Between Enormous Challenges and Inadequate Responses: Religion in the Nineties in This Region, in: Milan Vukomanović/Marinko Vučinic (eds.): Religious Dialogue in the Balkans: The Drama of Understanding. Belgrade: Belgrade Open School, 2005, pp. 43-6o.

Vukomanović, Milan/Vučinić, Marinko: Interreligijski dijalog kao vid pomirenja u jugoistočnoj Evropi [Inter-religious dialogue as a way of reconciliation in South Eastern Europe]. Belgrad: Beogradska otvorena škola, 2001, https://fvm.academia. edu/MilanVukomanović (date of last access: 15.02.2020).

Vukomanović, Milan: The Religious Dimension of the Yugoslav Conflicts, 2004 on Academia, https://www.academia.edu/2962428/The_Religious_Dimension_of_the_ Yugoslav_Conflicts (date of last access: 18.05.2020).

Official Gazette of $\mathrm{BiH}_{5}$ /o4: Zakon o slobodi vjere i pravnom položaju crkava i vjerskih zajednica u BiH".

Zovkić, Mato: Dialogue between Catholics and Muslims in Bosnia and Herzegovina. Sarajevo: CNS, 2018. 